\title{
Analysis of potential genes for the development of potatoes (Solanum tu- berosum) with heat stress-tolerance
}

\author{
Bernadetta Rina Hastilestari * \\ Pusat Penelitian Bioteknologi, Lembaga Ilmu Pengetahuan Indonesia, Bogor 16911, Indonesia
}

${ }^{*}$ Corresponding author:

E-mail:

Bernadetta.hastilestari@gmail.com

\begin{abstract}
Potato (Solanum tuberosum) is a widely cultivated plant in the highlands. Low temperature, such as temperature at night, is required for tuber formation. However, global warming has increased global temperature and causing a decrease in crop yields. To meet the growing demand for potatoes, the planting area needs to be expanded. Planting can be done at the medium-altitude or even lowland by developing potato varieties that are well-adapted to a higher temperature. The first step to achieve this goal is to analyze the potential genes for potato breeding by comparing the data from the microarray. Genes related to heat shock proteins affect the resistance of potato plants towards the increasing temperatures in the environment.
\end{abstract}

Keywords: Solanum tuberosum, heat stress, Heat Shock Protein

\section{Introduction}

The demand for potatoes (Solanum tuberosum) in Indonesia continues to increase along with dietary changes in modern society. Potato contains a lot of starch, vitamins, and minerals (Camire et al., 2009). Potato cultivation is mostly done in highland areas. This is because the potato was originated from the Andes in Peru, which is located in the highland with low temperatures, high light intensity, and short-day length (Rodríguez-Falcón et al., 2006). Potatoes from this area are diploid and known as Andean varieties (Hardigan et al., 2017). Along with the development of science, potatoes were brought out of Andes, underwent selection, and crossed to develop a variety that can adapt in areas with longer day length (Rodríguez-Falcón et al., 2006). This potato variety is then known as the modern potato that is generally tetraploid and can adapt to the temperature range between 14 to $22^{\circ} \mathrm{C}$ (Birch et al., 2012). If potatoes are grown above the optimum temperature, the tuber yield will decrease and the biomass will be accumulated in the stems and leaves (Lafta \& Lorenzen, 1995; Wolf et al., 1991). This condition might be worsened by global warming, as temperature increase will cause the yield to decrease by 18 to $22 \%$ (Hijmans, 2003).

An increase in temperature can affect the physiological condition of plants (Lafta \& Lorenzen, 1995; Hatfield \& Prueger, 2015), such as reduced cell membrane stability due to the $\mathrm{Ca}^{2+}$ influx from the Endoplasmic Reticulum (ER) to the cytosol. These ions will affect the signaling process and cause changes in plant gene expression. Plants will respond to temperature increase by increasing the expression of Heat Shock Protein (HSP) to protect against protein misfolding (Sung et al., 2001).

Physiological changes due to heat stress on Agria variety have been reported and their gene expressions have been analyzed using microarray (Hastilestari et al., 2018). Another experiment set has been conducted using Desiree variety (Hancock et al., 2014). Those two varieties are morphologically different, as Agria variety has brownish-yellow tuber skin while the Desiree variety is red. This study aims to investigate the results of the two microarrays from the above-mentioned varieties to find the genes that have similar expressions when exposed to

\section{How to cite:}

Hastilestari, B. R. (2021). Analysis of potential genes for the development of potatoes (Solanum tuberosum) with heat stress-tolerance. Basic and Applied Science Conference (BASC) 2021. NST Proceedings. pages 8-14. doi: 10.11594/ nstp.2021.1102 
heat. Thus, the candidate genes are expected to be found and then can be used for the development of heat-tolerant potato plants.

\section{Material and Methods}

The results of microarray carried out by Hastilestari et al. (2018) in Agria variety and Hancock et al. (2014) in Desiree variety were compared and analyzed in this study. Furthermore, the gene expressions of two microarrays results were aligned and categorized into functional groups.

Four treatments were applied on S. tuberosum cv. Agria for 14 days before conducting microarray analysis by Hastilestari et al. (2018). The treatments consisted of control, heat stress on roots, heat stress on stems, and overall heat stress. The control plants were kept under 16-hours of light at $22^{\circ} \mathrm{C}$ and followed by 8 -hours dark at $20^{\circ} \mathrm{C}$. The plants assigned to root heat stress treatment were given $29^{\circ} \mathrm{C}$ temperature treatment on their roots, while their stems were treated similarly as control. The stem heat stress was done by giving $29^{\circ} \mathrm{C}$ temperature treatment under 6hours of light, followed by 8 -hours dark at $27^{\circ} \mathrm{C}$ to the stem, while the roots were cooled at $22^{\circ} \mathrm{C}$. Plants that were subjected to overall heat stress were kept under 16 -hours of light at $29^{\circ} \mathrm{C}$, followed by 8 -hours dark at $27^{\circ} \mathrm{C}$. On the other hand, S. tuberosum cv. Desiree used by Hancock et al. (2014) were given 2 different treatments. The control plant group was kept under 16-hours of light at $22^{\circ} \mathrm{C}$ and followed by 8 -hours dark at $20^{\circ} \mathrm{C}$. Meanwhile, the heat-treated plants were kept under 16-hours of light at $30^{\circ} \mathrm{C}$ and 8 -hours dark at $20^{\circ} \mathrm{C}$.

The results of two microarrays were then aligned and categorized into functional groups based on their gene expressions. Out of 4 different treatments performed by Hastilestari et al. (2018), we used data from control and plants that were given heat-stress treatment on all of their parts. Based on the two microarray results, the gene expressions with similar responses while heatstress treatment were compared to control plants.

\section{Results and Discussion}

There are about 34 potato varieties in Indonesia (Table 1). Most of them are cultivated in highland altitude areas with varying tuber yields, around 1.5 to 40 tons per hectare. The varieties with the lowest yields are the Golden Agrihorta and Papita Agrihorta, with around 1.5 to 2 tons of yield per hectare, while the Spudy Agrihorta has the highest yields with 27.6-40.8 tons/hectare. Olimpus Agrihorti variety can be cultivated in the lowlands with a yield of 15.5-23.3 tons/hectare. On the other hand, Granola and Supejohn varieties are reported to experience almost $20 \%$ yield reduction when cultivated at $750 \mathrm{~m}$ above sea level compared to $1200 \mathrm{~m}$ above sea level (Mailangkay et al., 2012). The different temperatures on different elevations of the planting site are reported to be the most influential factor on tuber weight compared to other factors, such as light intensity. This theory is supported by Sa'diyyah et al. (2017) who reported that there are no differences in tuber weight at different light intensities. On the other hand, genetic variation is also reported to be one of the factors that affecting tuber weight.

Table 1. Potato varieties in Indonesia

\begin{tabular}{llcccc}
\hline No & Variety & $\begin{array}{c}\text { Re- } \\
\text { leased } \\
\text { year }\end{array}$ & $\begin{array}{c}\text { Yields } \\
\text { (Tons per Ha) }\end{array}$ & $\begin{array}{c}\text { Adaptation } \\
\text { Area }\end{array}$ & $\begin{array}{c}\text { Refer- } \\
\text { ences }\end{array}$ \\
\hline 1 & Amabile & 2013 & $25.7-29.2$ & $>1200$ masl & 1 \\
2 & Amudra & 2002 & $20.0-42.0$ & n/a & 1 \\
3 & Andina & 2011 & $20.4-34.1$ & $1250-1500$ masl & 1 \\
4 & AR 07 Agrihorti & 2015 & $24.9-1.30$ & Highland & 1 \\
5 & AR 08 Agrihorti & 2015 & $28.9-2.10$ & Highland & 1 \\
6 & Atlantik Malang & 1999 & 8.020 & n/a & 1 \\
& To be continued... & & & & \\
\hline
\end{tabular}




\begin{tabular}{clcccc}
\hline 7 & Balsa & 2005 & 22.4 & Highland & 1 \\
8 & Cipanas & 1980 & 1334 & Highland & 1 \\
9 & Cosima & 1980 & $19-36$ & n/a & 1 \\
10 & Dayang sumbi Agrihorta & 2016 & $23.3-29.8$ & Highland & 1 \\
11 & Erika & 2005 & 25.3 & Highland & 1 \\
12 & Fries & 2005 & 25.7 & Highland & 1 \\
13 & GM05 & 2009 & $29.1-35.8$ & $1.200-1.650$ masl & 1 \\
14 & GM08 & 2009 & $27.4-34.2$ & $1.200-1.650$ masl & 1 \\
15 & Golden Agrihorta & n/a & $1.50-2.00$ & Highland & 1 \\
16 & Granola L & 2002 & 26.5 & Highland & 1.2 \\
17 & Kastanum & 2011 & $24.50-34.03$ & $1.250-1.500$ masl & 1 \\
18 & Kikondo & 2008 & $18-24$ & $1.000-2.000$ masl & 1 \\
19 & Krespo & 2005 & 28.1 & Highland & 1 \\
20 & Maglia & 2013 & $24.0-29.2$ & 1.200 masl & 1 \\
21 & Manohara & 1999 & $20-37$ & Highland & 1 \\
22 & Margahayu & 2008 & $18-23$ & $1.000-2.000$ masl & 1 \\
23 & Medians & 2013 & $24.9-31.9$ & 1.200 masl & 1 \\
24 & Merbabu 17 & 2000 & 24 & Highland & 1 \\
25 & Olimpus Agrihorti & 2015 & $15.5-23.3$ & Medium altitude & 1 \\
26 & Papita Agrihorti & 2019 & $1.5-2.0$ & Highland & 1 \\
27 & Ping 06 & 2009 & $29.1-38.3$ & $1.250-1.650$ masl & 1 \\
28 & Repita & 2005 & $30-32$ & 1.000 masl & 1 \\
29 & Spudy Agrihorti & 2018 & $27.6-40.8$ & Highland & 1 \\
30 & Supejohn & $\mathrm{n} / \mathrm{a}$ & $\mathrm{n} / \mathrm{a}$ & Highland & 2 \\
31 & Tenggo & 2005 & 33.5 & Highland & 1 \\
32 & Sangkuriang Agrihorti & 2016 & $24.6-34.9$ & Highland & 1 \\
33 & Ventrury Agrihorta & $\mathrm{n} / \mathrm{a}$ & $23.2-32.9$ & Highland & 1 \\
34 & Vernei & 2011 & $21.1-35.6$ & $1.250-1.500$ masl & 1 \\
\hline & & & & \\
& & & & \\
\hline
\end{tabular}

Source: 1. Humas Balitsa. (2019); 2. Mailangkay et al., (2012).

Genetic variation needs to be analyzed to determine which transcripts are affected by heat stress. According to Hastilestari et al. (2018), there were 2950 transcripts detected on Agria variety leaves that were affected by heat stress in both control and heat-stress treatments. Meanwhile, Hancock et al. (2013) stated that 2190 transcripts were affected by heat stress in the Desiree variety leaves. After the alignment of both microarray data, we found 684 transcripts that were affected by heat stress on both varieties. Furthermore, the transcripts were grouped into 21 functional groups, namely hormones, lipid metabolism, various functions, energy metabolism, unknown functions, proteins, photosynthesis, redox, ribonucleic acid (RNA), secondary metabolism, signaling, stress, amino acids, cell walls, cells, growth, DNA, minor CHO metabolism, primary carbon metabolism, and transport (Figure 1). The categorization showed that the largest percentage belongs to the group of genes whose function is unknown $(33.23 \%)$, followed by protein (12.15\%), RNA (9.66\%), and stress $(9.22 \%)$. 


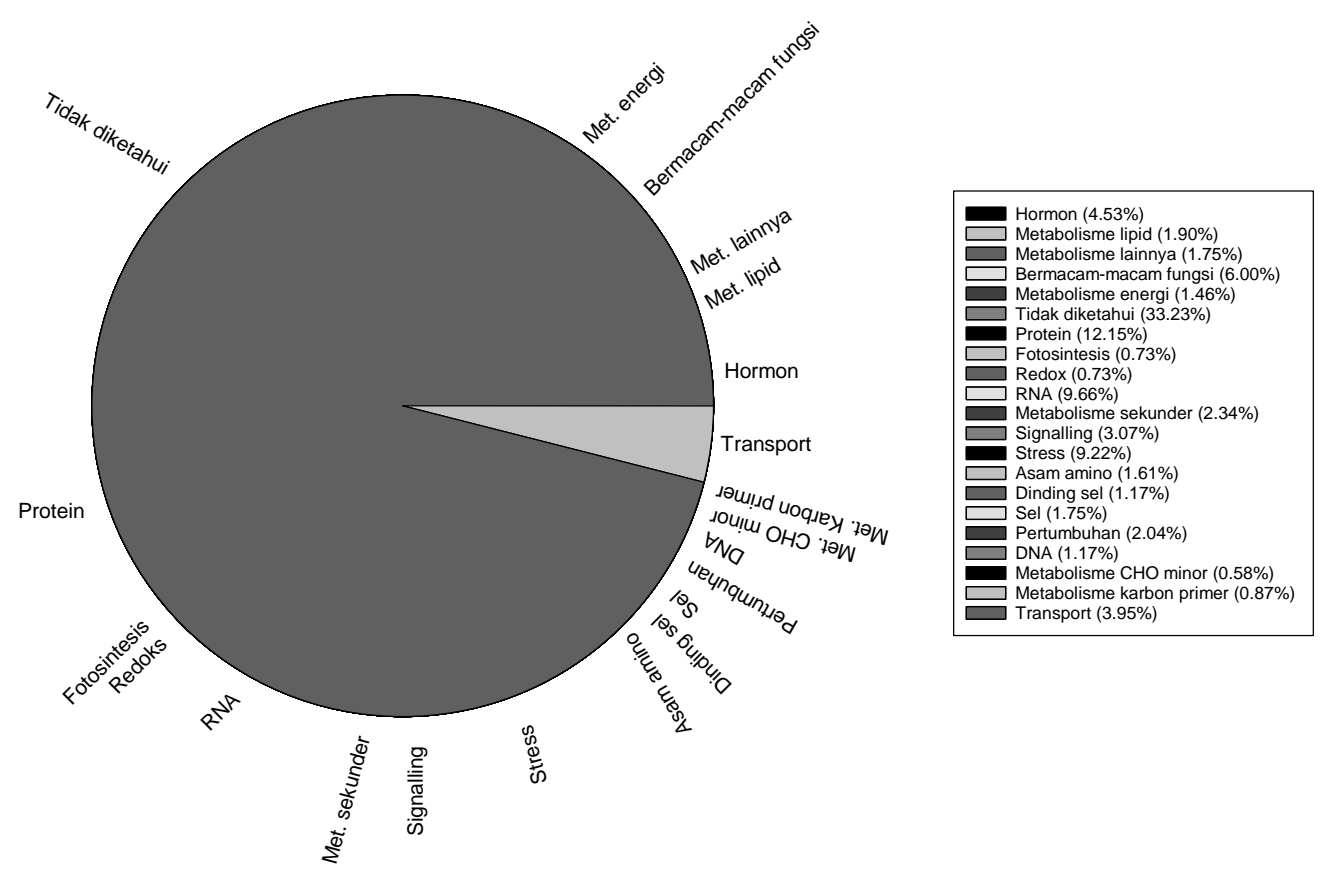

Figure 1. The functional groups of genes are affected by heat stress according to Hastilestari et al. (2014) and Hancock et al. (2018).

Out of all the observed protein functional groups, the genes affected by heat stress were dominated by ubiquitin-protein that functions as a degradation protein. Ubiquitin protein has a role in adaptation to stress, such as heat stress (Xu \& Xue, 2019). Furthermore, the E3 ligase protein was also found to be the most abundant protein in the microarray results from both Agria and Desiree varieties. This protein has a role to respond to environmental stimuli by influencing the transcription factors underneath (Lyzenga \& Stone, 2012).

The third most abundant functional group was RNA, which consisted of transcription factors. These transcription factors play an important role in transmitting the received signal when there is heat stress by interacting with the cis-element in the promoter so that the stress-related genes can be expressed (Akhtar et al., 2012). The stress functional group ranked fourth on the functional groups affected by heat stress. From both microarray data sets, HSP-associated transcripts had a higher expression when plants were exposed to heat stress compared to control (Figure 2). The heat shock protein group that had a relatively high expression was small HSP-chloroplastic (PGSC0003DMG400003219), sHSP protein homolog (PGSC0003DMG400009255), Class II sHSP le-HSP 17.6 (PGSC0003DMG400021737), and HSP (PGSC0003DMG400028634).

The microarray data by Hancock et al. (2014) (Figure 2.II) indicated that plants exposed to heat stress had a higher increase in HSP-related transcripts compared to the study by Hastilestari et al. (2018) (Figure 2.I). This phenomenon may be due to the differences in the heat stress treatment between the two studies. Hancock et al. (2014) used heat treatment at $30^{\circ} \mathrm{C}$ and $20^{\circ} \mathrm{C}$ with light or dark treatments and showed the higher result. Meanwhile, Hastilestari et al. (2018) used heat treatment with a temperature of $29^{\circ} \mathrm{C}$ or $27^{\circ} \mathrm{C}$. 

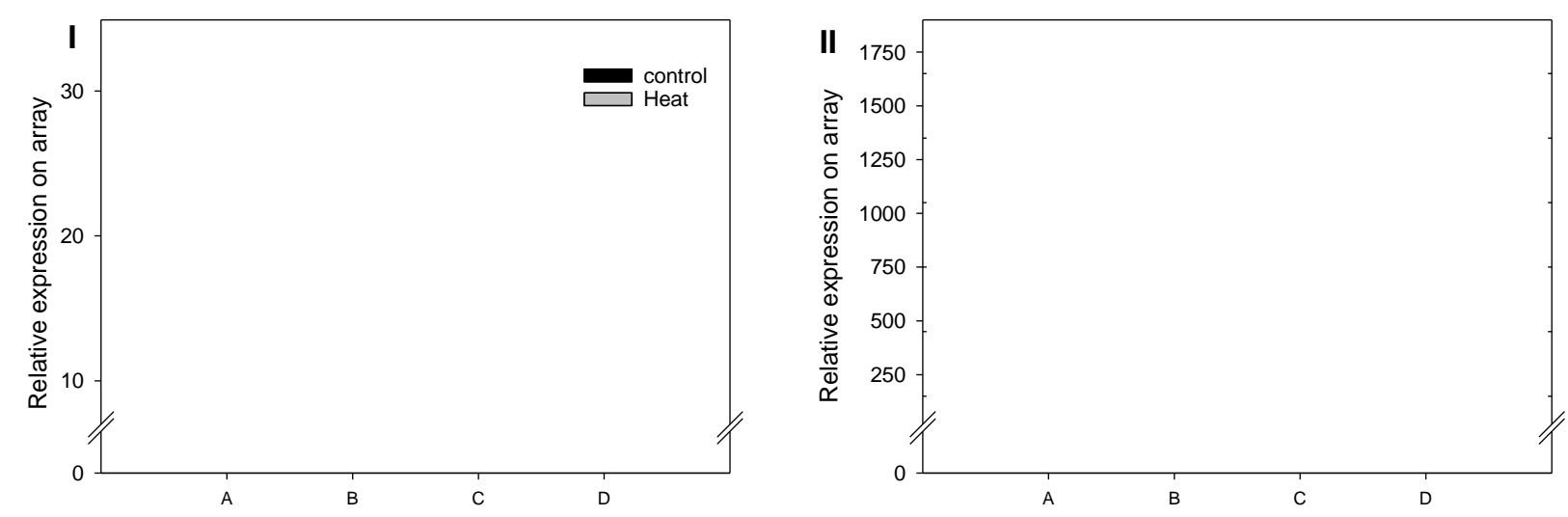

Figure 2. Relative HSP expressions I) by Hastilestari et al. (2018) and II) by Hancock et al. (2014). Accession number: A) sHSP-chloroplastic (PGSC0003DMG400003219); B) sHSP protein homolog (PGSC0003DMG400009255); C) Class II sHSP le-HSP 17.6 (PGSC0003DMG400021737); and D) HSP (PGSC0003DMG400028634)

Hancock et al. (2014) reported that the sHSP protein (PGSC0003DMG400009255) expression on the plants' given heat-stress treatment has increased 1.000 times, while Hastilestari et al. (2018) reported only 30 times to increase after heat-stress treatment. This gene is homologous to AT4G10250 from Arabidopsis thaliana, which is reported to play a role in giving respond to heat stress and other abiotic stress, such as osmotic stress and salinity. Besides, this gene also plays a role in cell proliferation and differentiation (Ogawa et al., 2007).

Based on the microarray data obtained by Hastilestari et al. (2018) (Figure 2.I A), the relative expression of sHSP-chloroplastic (PGSC0003DMG400003219) transcripts was increased about 12 times after heat-stress treatment. Meanwhile, the data from Hancock et al. (2014) showed 300 times increase after heat-stress treatment (Figure 2.II A). This gene is located on the chloroplast and reported to be homologous to HSP21 (AT4G27670) from A. thaliana. This gene is known to interact with a nuclear protein called pTAC5 that has a role in chloroplast development when $A$. thaliana encounters heat-stress conditions (Zhong et al., 2013).

The expression of PGSC0003DMG40002173 transcript, known as Class II sHSP le-HSP 17.6, was increased 9 times in Agria variety after $29^{\circ} \mathrm{C}$ heat-stress treatment and increased 50 times in Desiree variety after $30^{\circ} \mathrm{C}$ heat-stress treatment. This gene has a role to stabilize the protein that is denatured under heat-stress conditions. This gene has a high similarity with A. thaliana HSP 17.6 A (AT5G12030) (Mymrikov et al., 2011; Siddique et al., 2008; Sun et al., 2002).

Based on the microarray results obtained by Hastilestari et al. (2018), the expression of HSPrelated PGSC0003DMG400028634 transcripts was increased 9 times after heat-stress treatment, while Hancock et al. (2014) results showed 375 times increase in its expression after heat-stress treatment. This transcript is almost identical to HSP70 of $A$. thaliana (AT1G16030), which acts as a chaperone in the protein folding process according to TAIR (The Arabidopsis Information Resource, Lamesch et al., 2011). The potato plants with overexpressed Heat Shock Cognate (HSC 70) were reported to have reduced adverse effects of heat stress. They also added that overexpression of HSC70 was able to stabilize the crop yields.

Despite having different tuber morphologies, the potato plants' resistance to heat stress is influenced by the same genes, which are related to HSP. The higher the environmental temperature, the higher the expression of these genes. Thus, to develop a novel high-yielding variety of potato plants with heat-stress resistant properties for cultivation on the middle elevation and lowlands, it is necessary to have a parental variety that has a high expression of genes associated with HSP. 


\section{Conclusion}

Based on the gene expressions obtained from Hastilestari et al. (2018) and Hancock et al. (2013) on different potato varieties (Agria and Desiree, respectively), the largest functional group associated with heat stress belongs to a gene group with unidentified functions, followed by protein, RNA and stress groups. The stress group was dominated by the HSP group with the highest expression recorded from the sHSP protein homolog (PGSC0003DMG400009255). Although the two potato varieties have different tuber morphology, both resistance against heat stress is influenced by similar HSP gene groups. Therefore, local varieties with high HSP gene expression can be used as parents in the development of novel potato high-yielding varieties with heat-stressresistant.

\section{References}

Akhtar, M., Jaiswal, A., Taj, G., Jaiswal, J. P., Qureshi, M. I., \& Singh, N. K. (2012). DREB1/CBF transcription factors: their structure, function and role in abiotic stress tolerance in plants. Journal of genetics, 91(3), 385-395.

Birch, P. R., Bryan, G., Fenton, B., Gilroy, E. M., Hein, I., Jones, J. T., Prashar, A., Taylor, M. A., Torrance, L., \& \& Toth, I. K. (2012). Crops that feed the world 8: potato: are the trends of increased global production sustainable?. Food Security, 4(4), 477-508. https://doi.org/10.1007/s12571-012-0220-1

Camire, M. E., Kubow, S., \& Donnelly, D. J. (2009). Potatoes and human health. Critical Reviews in Food Science and Nutrition, 49(10), 823-840. Doi: 10.1080/10408390903041996

Hancock, R. D., Morris, W. L., Ducreux, L. J., Morris, J. A., Usman, M., Verrall, S. R., Fuller, J., Simpson, C. G., Zhang, R., Hedley, P. E., \& Taylor, M. A. (2014). Physiological, biochemical and molecular responses of the potato (Solanum tuberosum L.) plant to moderately elevated temperature. Plant, cell \& environment, 37(2), 439-450. Doi: 10.1111/pce.12168

Hatfield, J. L., \& Prueger, J. H. (2015). Temperature extremes: Effect on plant growth and development. Weather and climate extremes, 10, 4-10.

Hardigan, M. A., Laimbeer, F. P. E., Newton, L., Crisovan, E., Hamilton, J. P., Vaillancourt, B., Wiegert-Rininger, K., Wood, J. C., Douches, D. S., Farre, E. M., Veilleux, R. E., \& Buell, C. R. (2017). Genome diversity of tuber-bearing Solanum uncovers complex evolutionary history and targets of domestication in the cultivated potato. Proceedings of the National Academy of Sciences, 114(46), E9999E10008. https://doi.org/10.1073/pnas.1714380114

Hastilestari, B. R., Lorenz, J., Reid, S., Hofmann, J., Pscheidt, D., Sonnewald, U., \& Sonnewald, S. (2018). Deciphering source and sink responses of potato plants (Solanum tuberosum L.) to elevated temperatures. Plant, cell \& environment, 41(11), 2600-2616. Doi: 10.1111/pce.13366

Hijmans, R. J. (2003). The effect of climate change on global potato production. American journal of potato research, 80(4), $271-279$.

Humas Balitsa. (2019). Variertas kentang. https://balitsa.litbang.pertanian.go.id/ind/index.php/varietas/kentang

Lafta, A. M., \& Lorenzen, J. H. (1995). Effect of high temperature on plant growth and carbohydrate metabolism in potato. Plant Physiology, 109(2), 637-643. doi: 10.1104/pp.109.2.637.

Lamesch, P., Berardini, T.Z., Li, D., Swarbreck, D., Wilks, C., Sasidharan, R., Muller, R., Dreher, K., Alexander, D.L., Garcia-Hernandez, M., Karthikeyan, A.S., Lee, C.H.,Nelson, W.D., Ploetz, L., Singh, S., Wensel, A., \& Huala, E. (2012). The Arabidobsis Information Resource (TAIR): Improved gene annotation and new tools. Nucleic Acids Res. 40, D1202-10. doi: 10.1093/nar/gkr1090.

Lyzenga, W. J., \& Stone, S. L. (2012). Abiotic stress tolerance mediated by protein ubiquitination. Journal of experimental botany, 63(2), 599-616. Doi: 10.1093/jxb/err310

Mailangkay, B. H., Paulus, J. M., \& Rogi, J. E. (2012). Pertumbuhan dan produksi dua varietas kentang (Solanum tuberosum L.) pada dua ketinggian tempat. EUGENIA, 18(2), 7-12. DOI: https://doi.org/10.35791/eug.18.2.2012.3954

Mymrikov, E. V., Seit-Nebi, A. S., \& Gusev, N. B. (2011). Large potentials of small heat shock proteins. Physiological reviews, 91(4), 11231159. doi: 10.1152/physrev.00023.2010.

Ogawa, D., Yamaguchi, K., \& Nishiuchi, T. (2007). High-level overexpression of the Arabidopsis HsfA2 gene confers not only increased themotolerance but also salt/osmotic stress tolerance and enhanced callus growth. Journal of experimental botany, 58(12), 33733383. doi: 10.1093/jxb/erm184

Rodríguez-Falcón, M., Bou, J., \& Prat, S. (2006). Seasonal control of tuberization in potato: conserved elements with the flowering response. Annu. Rev. Plant Biol., 57, 151-180. doi: 10.1146/annurev.arplant.57.032905.105224. 
Sa'diyyah, I., Damanhuri, F. N. U., \& Erdiansyah, I. (2017). Adaptasi Pertumbuhan Dua Varietas Kentang (Solanum tuberosum L.) terhadap Pemberian Naungan: Kajian Pengembangan Budidaya di Dataran Menengah. Agriprima, Journal of Applied Agricultural Sciences, 1(2), 185-194. Doi: https://doi.org/10.25047/agriprima.v1i2.33

Siddique, M., Gernhard, S., von Koskull-Döring, P., Vierling, E., \& Scharf, K. D. (2008). The plant sHSP superfamily: five new members in Arabidopsis thaliana with unexpected properties. Cell Stress and Chaperones, 13(2), 183-197. doi: 10.1007/s12192-008-0032-6

Sun, W., Van Montagu, M., \& Verbruggen, N. (2002). Small heat shock proteins and stress tolerance in plants. Biochimica et Biophysica Acta (BBA)-Gene Structure and Expression, 1577(1), 1-9. Doi: 10.1016/s0167-4781(02)00417-7.

Sung, D., Kaplan, F., and Guy, C.L. (2001). Plant Hsp70 molecular chaperones: Protein structure, gene family, expression and function. Physiol. Plant. 113, 443-451. https://doi.org/10.1034/j.1399-3054.2001.1130402.x

Wolf, S., Marani, A., \& Rudich, J. (1991). Effect of temperature on carbohydrate metabolism in potato plants. Journal of Experimental Botany, 42(5), 619-625. https://doi.org/10.1093/ixb/42.5.619

Xu, F. Q., \& Xue, H. W. (2019). The ubiquitin-proteasome system in plant responses to environments. Plant, cell \& environment, 42(10), 2931-2944. https://doi.org/10.1111/pce.13633

Zhong, L., Zhou, W., Wang, H., Ding, S., Lu, Q., Wen, X., \& Lu, C. (2013). Chloroplast small heat shock protein HSP21 interacts with plastid nucleoid protein pTAC5 and is essential for chloroplast development in Arabidopsis under heat stress. The Plant Cell, 25(8), 2925-2943. 